\title{
Ricin Immunoconjugate
}

National Cancer Institute

\section{Source}

National Cancer Institute. Ricin Immunoconjugate. NCI Thesaurus. Code C2359.

A ricin-containing immunotoxin with immunotherapeutic property. Ricin, a plant toxin extracted from castor beans, inhibits protein synthesis via cleaving ribosomal subunit $28 \mathrm{~S}$ rRNA. Ricin immunoconjug ate consists of specific antibody conjugated with the blocked ricin (bR), which has the galactose-binding sites of the B-chain blocked while leaving the ribosome-inactivating ricin A-chain intact, thereby attaining cell-type-specific immunotoxins. 